AYKUT ERKAL, Ph.D.

E-mail: aykut.erkal@altinbas.edu.tr

İstanbul Altınbaş University

Department of Civil Engineering

Mahmutbey Dilmenler Caddesi, No:26, 34217 Bağcılar,

İstanbul, Turkey
Traffic and Environment (Ecology)

Original Scientific Paper

Submitted: 15 May 2018

Accepted: 4 Apr. 2019

\title{
IMPACT OF TRAFFIC-INDUCED VIBRATIONS ON RESIDENTIAL BUILDINGS AND THEIR OCCUPANTS IN METROPOLITAN CITIES
}

\begin{abstract}
This paper evaluates and quantifies the adverse impact of traffic-induced vibrations on the structural systems of residential buildings and their occupants. To do this, İstanbul, one of the world's most populous and traffic-congested cities, was selected as a case study. Firstly, a survey was conducted on 100 occupants of six neighbourhoods to understand human perception of vibrations and the physical condition of typical buildings. Then, train-induced ground vibrations were measured near a busy railway. Using the survey data and the measured train vibrations, time-history analyses were applied to five typical residential buildings. The results showed that there is a considerable contribution of higher modes to overall building response. Peak particle velocities calculated on the buildings are predominantly in tolerable. Critically, 95\% of the occupants would like authorities to reorganize traffic regulations to reduce the effects of this global problem. Therefore, human response to traffic-induced vibrations should be consideration of serviceability limit state and site-specific analysis should be incorporated into the codes of practice.
\end{abstract}

\section{KEY WORDS}

traffic-induced vibrations; human-traffic interaction; perception of vibrations; building-traffic interaction; vibration measurement;

\section{INTRODUCTION}

Increase in urban population has brought the previously constructed residential buildings into much closer proximity with the main arteries of the world's large cities. Buildings and their occupants have been adversely affected by vibrations induced by traffic in metropolitan cities as these vibrations are becoming more perceptible, disturbing and thus undesirable. To begin with, local authorities in large cities encourage the use of public transportation systems instead of private vehicles to reduce air pollution. Because of this, the operation of heavy and high-capacity transportation systems is growing, and thus traffic-induced vibrations are becoming more prevalent since the weight of a vehicle has a considerable effect on the generation of these vibrations [1]. Additionally, the increasing demand for road or rail construction brings the existing buildings into much closer proximity to these transportation networks. The nearer the structures are to the sources of vibration, the stronger the impact of traffic-induced stress waves propagating through the soil into the structures. Furthermore, recently designed high-speed railway lines escalate the magnitude of this problem since higher-amplitude vibrations occur for higher-speed vehicles [2]. The topography and soil profile are also major factors. Given that the soil in urban areas is generally heterogeneous and layered; this could even lead to amplification of ground vibrations [3]. Moreover, inadequate design or poor maintenance of transportation systems can cause wear of railway tracks or defects of train wheels as well as surface irregularities on the road surfaces. The dynamic response of vehicles during these surface interactions contributes significantly to ground vibrations [4]. As a result, concerns about the negative effects of traffic-induced vibrations [5], growing in a number of large cities, require comprehensive and systematic investigation.

\section{Aims and methodology}

Structural effects of traffic-induced vibrations have not been fully researched mainly due to their low amplitude, compared to seismic and nearby blast-induced vibrations. However, the continuous, repetitive and prolonged nature of traffic-induced vibrations can cause insidious effects on the structures [6]. There are even specific applications to protect the structures of great value against these vibrations [7]. Additionally, some of the previously conducted studies investigated the lateral response of two-dimensional (2-D) frame structures only [8] and some used artificial vibration data instead of recorded real data [9]. Filling such gaps, this study aims to comprehensively analyse human and three-dimensional (3-D) building response to 3-D traffic-induced vibrations based on a social survey and numerical modelling of buildings. To do this, İstanbul was selected as a case study since 
it is currently one of the megacities of the world with a population of 14.8 million (18.5\% of population of Turkey) as of 2016 [10]. Six densely populated areas of İstanbul with heavy road and/or rail traffic were identified. In these areas, two sets of personal interview surveys were conducted with 100 people aiming to reveal (1) physical properties of buildings and (2) the effects of traffic-induced vibrations on occupants and buildings. Based on the survey, five typical residential reinforced-concrete $(\mathrm{RC})$ buildings were mathematically modelled and then modal analysis and linear time-history analyses were conducted. In the time-history analyses, three different train-induced ground motions, measured near the Sirkeci-Halkalı railway line in İstanbul, were applied to the models. Displacement, velocity and acceleration responses of buildings along with their dynamic properties were presented and discussed to show the overall picture for different structural and ground motion parameters.

\section{SURVEY}

Based on the perception of occupants, survey questionnaires were carried out to collect their responses. A representative sample of interviewees, living close to road and/or rail traffic was randomly selected to minimize the bias. Interviewee selection method was also governed by the intelligibility, willingness, sufficient exposure to vibrations and age variation of the interviewees. The questionnaires were conducted on 100 occupants face-to-face in 38 buildings in six different busy areas of Istanbul. Apart from high population density, vulnerability of buildings is the other criterion that makes these areas high-risk in terms of ground motions. Similar concerns, reported for these areas in "Earthquake Risk Assessment for Istanbul Metropolitan Area" [11], justify their selection as well. The main reasons for their selection for investigation are presented in Table 1.

The first part of the questionnaire aims to explore the attitude of occupants regarding perception of and concern about nearby traffic-induced vibrations. The interview questions are principally about personal information, sensitivity, annoyance, occupancy and future expectations of the occupants. This part included multiple-choice questions with a sufficiently comprehensive set of predefined answer options, e.g. the ranges of time periods and frequency of feelings of people about vibrations. The choices for answers are shown in the figures of Section 6.1. Additionally, the interviewees were reminded to distinguish between ground-borne and airborne vibrations as the noise of road and rail traffic may also cause vibrations. Airborne vibrations generally have higher frequencies than ground-borne vibrations and may cause rattling of windows and loose objects mainly in the front rooms of the nearby buildings. This part consisted of 14 questions:

1) How old are you?

2) How long have you been living in this building?

3) Which floor do you live on?

4) How perceptible do you find the nearby traffic-induced vibrations?

Table 1 - Characteristics of surveyed areas

\begin{tabular}{|c|c|c|c|}
\hline District and Route & Reason for investigation & Type of traffic & $\begin{array}{c}\text { Number of } \\
\text { interviewees }\end{array}$ \\
\hline $\begin{array}{l}\text { Bayrampaşa, } \\
\text { Sağmalcılar }\end{array}$ & $\begin{array}{l}\text { - Both heavy rail \& road traffic } \\
\text { - Variety of road vehicles } \\
\text { - Proximity of buildings to the traffic (even the pavement width } \\
\text { is relatively narrow) } \\
\text { - Busy metro railway }\end{array}$ & $\begin{array}{l}\text { Road traffic \& } \\
\text { Railway traffic }\end{array}$ & 15 \\
\hline $\begin{array}{l}\text { Fatih, } \\
\text { Yeniçeriler Caddesi }\end{array}$ & $\begin{array}{l}\text { - Considerably densely populated area } \\
\text { - Busy tram traffic } \\
\text { - Age of the RC buildings }\end{array}$ & Railway traffic & 15 \\
\hline $\begin{array}{l}\text { Fatih, } \\
\text { Kennedy Caddesi }\end{array}$ & $\begin{array}{l}\text { - Relatively high-speed vehicles } \\
\text { - Intensive car traffic } \\
\text { - Age of the RC buildings }\end{array}$ & Road traffic & 15 \\
\hline $\begin{array}{l}\text { Beyoğlu, } \\
\text { Kemeraltı Caddesi }\end{array}$ & $\begin{array}{l}\text { - Both rail \& road traffic } \\
\text { - Intensive car traffic } \\
\text { - Busy tram traffic } \\
\end{array}$ & $\begin{array}{l}\text { Road traffic \& } \\
\text { Railway traffic }\end{array}$ & 15 \\
\hline $\begin{array}{l}\text { Kadıköy, } \\
\text { Bağdat Caddesi }\end{array}$ & $\begin{array}{l}\text { - High-speed vehicles } \\
\text { - Variety of road vehicles } \\
\text { - Intensive road traffic }\end{array}$ & Road traffic & 15 \\
\hline $\begin{array}{l}\text { Avcılar, D-100 } \\
\text { Güney Yanyolu }\end{array}$ & $\begin{array}{l}\text { - Close proximity of buildings to the traffic } \\
\text { - Intensive road traffic } \\
\text { - Variety of road vehicles } \\
\text { - Age of the RC buildings }\end{array}$ & Road traffic & 25 \\
\hline
\end{tabular}


5) How often do you physically feel traffic-induced vibrations?

6) How often do you get disturbed by the vibrations when you need rest or sleep?

7) How often do you experience the adverse effects of traffic-induced vibrations during indoor activities at home?

8) How often do the fixtures and fittings at home vibrate due to these vibrations?

9) Do you feel the vibration of the structural system of your building?

10) At which time period of the day do you feel the vibrations most?

11) How often do you worry that your building might be partially damaged or destroyed due to traffic-induced vibrations?

12) What causes the traffic-induced vibrations to be disturbing?

13) What type of vehicles causes most vibrations?

14) Do you think it is necessary for the authorities to reorganize traffic regulations to reduce the effects of traffic-induced vibrations on structures and people? The second part of the questionnaire aims to gather information about the structural and geometrical properties and the current condition of the buildings. The building size, number of stories and general dimensions of the structural elements are some of the aspects examined. The data collected herein helped to create mathematical models of the buildings to assess building response under the measured train-induced ground vibrations, which will be discussed in detail in the 6th section. This part comprised mainly open-ended questions with a short and specific piece of information without predefined answers. Some building parameters about which an interviewee was unsure were investigated together with the interviewer. This part consisted of nine questions:

1) What are the approximate dimensions of the base area of the building and the distance to the traffic route?

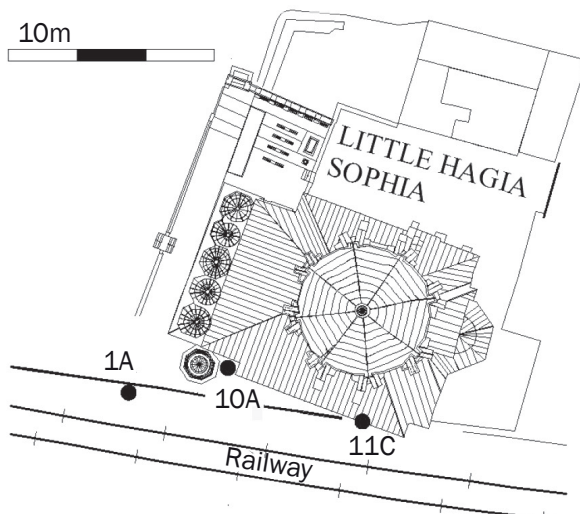

a) Test $1 \mathrm{~A}$, test $10 \mathrm{~A}$, test $11 \mathrm{C}$
2) What is the number of floors and the floor height of your building?

3) What is the number of apartments on a floor and the number of rooms in an apartment in the building?

4) What are the average cross-sectional dimensions of the largest and the smallest columns and beams in the building?

5) What is the approximate thickness of the slabs?

6) Are there shear walls in the structural system of your building? If yes, what are the dimensions of the cross-sectional area of an average shear wall?

7) Is there a soft story in the building?

8) How well-maintained is the building?

9) How old is your building?

\section{TRAIN-INDUCED GROUND MOTIONS}

Within the scope of a larger research program, train-induced ground motions were recorded next to the Sirkeci-Halkalı railway line in the district of Fatih. This site was specifically selected because two of the six surveyed areas in the social survey were also in Fatih, and the Sirkeci-Halkalı railway line serves some of the busy residential districts where many typical reinforced-concrete $(\mathrm{RC})$ buildings exist. Relatively different amplitudes and frequency contents of vibration records at different measurement locations were the other reasons for the selection of this specific site. Daily, 118 suburban trains (used for passenger transportation within the city), 6 intercity passenger trains, and 2 freight trains pass the site. The trains are generally comprised of 6 cars and travel at a speed of $70-90 \mathrm{~km} / \mathrm{h}$. Three perpendicular components of train-induced vibrations [vertical (Z), north-south (N-S), and east-west $(\mathrm{E}-\mathrm{W})]$ were measured using ultra-lightweight, three-component digital output seismometers (CMG-6TD). Within the physical constraints of the site, train vibrations were recorded on the ground, at the closest possible points to the railway. Figure 1 demonstrates the locations of seismographs labelled as A, $B, C, D$ and the preceding number indicates the test number.

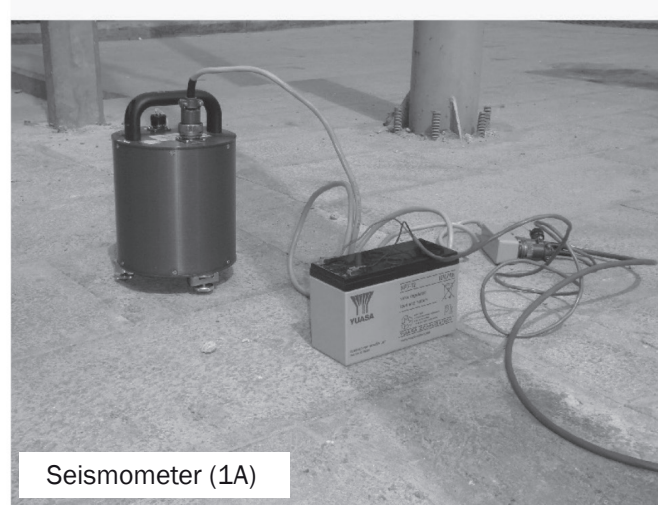

b) Sample instrumentation

Figure 1 - Vibration measurement locations by the railway line 
Although, passages of 3 trains in Test 1; 4 trains in Test 10 and 4 trains in Test 11 were recorded, only one train record in each test was used in the numerical modelling. This is because frequency content of ground vibrations at a point is mainly governed by the properties of soil around that point. Additionally, the trains produced horizontal vibrations with frequencies predominantly in the range from 5 to $80 \mathrm{~Hz}$, and this distributed vibrational energy can provide sufficient insight into the interaction of ground motions with the buildings. When different train-induced vibrations at the same measurement location were compared in each test, it was seen that the frequency content of each train passage was quite similar, but the amplitudes varied mainly due to train features. Therefore, the passage of a train with maximum vibration levels in each test was used in the time-history analyses. That is, the ground motions of Train 1 in Test $1(1 \mathrm{~A})$, Train 4 in Test 10 (10A) and Train 2 in Test 11 (11C) were used. Due to the high frequency nature of vibrations, a sampling rate of $500 \mathrm{~Hz}$ was assigned to allow a broad-range analysis. Table 2 presents the properties of vibrations.

Velocity time histories and corresponding Fourier spectra of recorded train-induced ground motions in three orthogonal directions [Z, N-S, and E-W] are illustrated in Figures 2, 3 and 4. The Fourier amplitude spectra basically express the distribution of the amplitude of the recorded ground motions with respect to frequency.

Table 2 - Properties of measured train-induced ground vibrations

\begin{tabular}{||l|c|c|c||}
\hline \multicolumn{1}{|c|}{ Name of test } & 1A (Train 1) & 10A (Train 4) & 11C (Train 2) \\
\hline \hline Time step [s] & 0.002 & 0.002 & 0.002 \\
\hline No. of data points $(N)$ & 8,000 & 10,000 & 9,500 \\
\hline Duration [s] & 16 & 20 & 19 \\
\hline Maximum Z Velocity [mm/s] & 2.01 & 0.33 & 0.83 \\
\hline Maximum N-S Velocity [mm/s] & 1.91 & 0.36 & 1.07 \\
\hline Maximum E-W Velocity [mm/s] & 1.23 & 0.26 & 1.22 \\
\hline Approximate Predominant Frequency Range $[\mathrm{Hz}]$ & $5-70$ & $5-55$ & $5-80$ \\
\hline
\end{tabular}
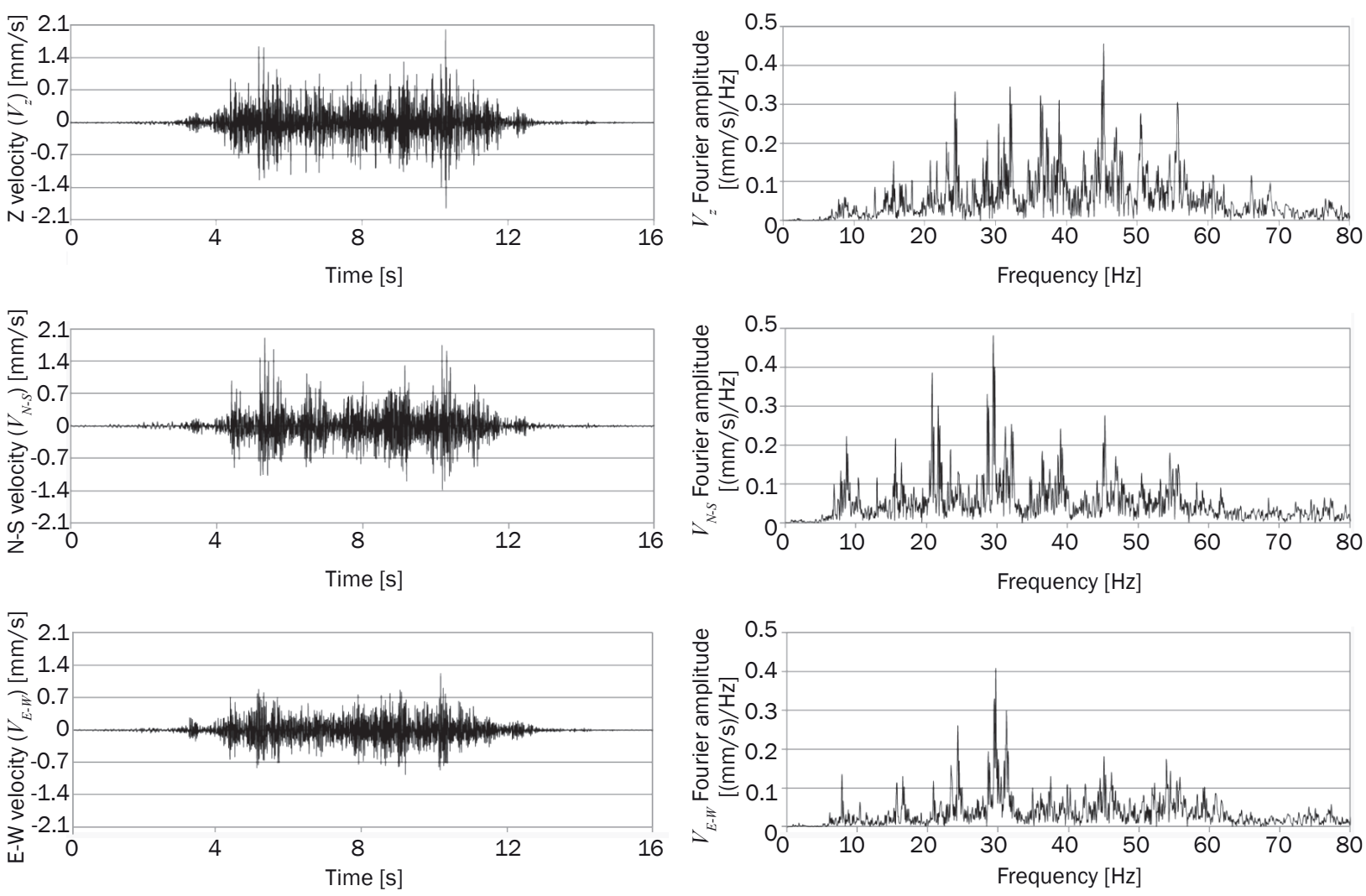

Figure 2 - Vertical (Z), north-south (N-S), east-west (E-W) velocity time histories and corresponding Fourier spectra of Train 1 in Test $1 \mathrm{~A}$ 

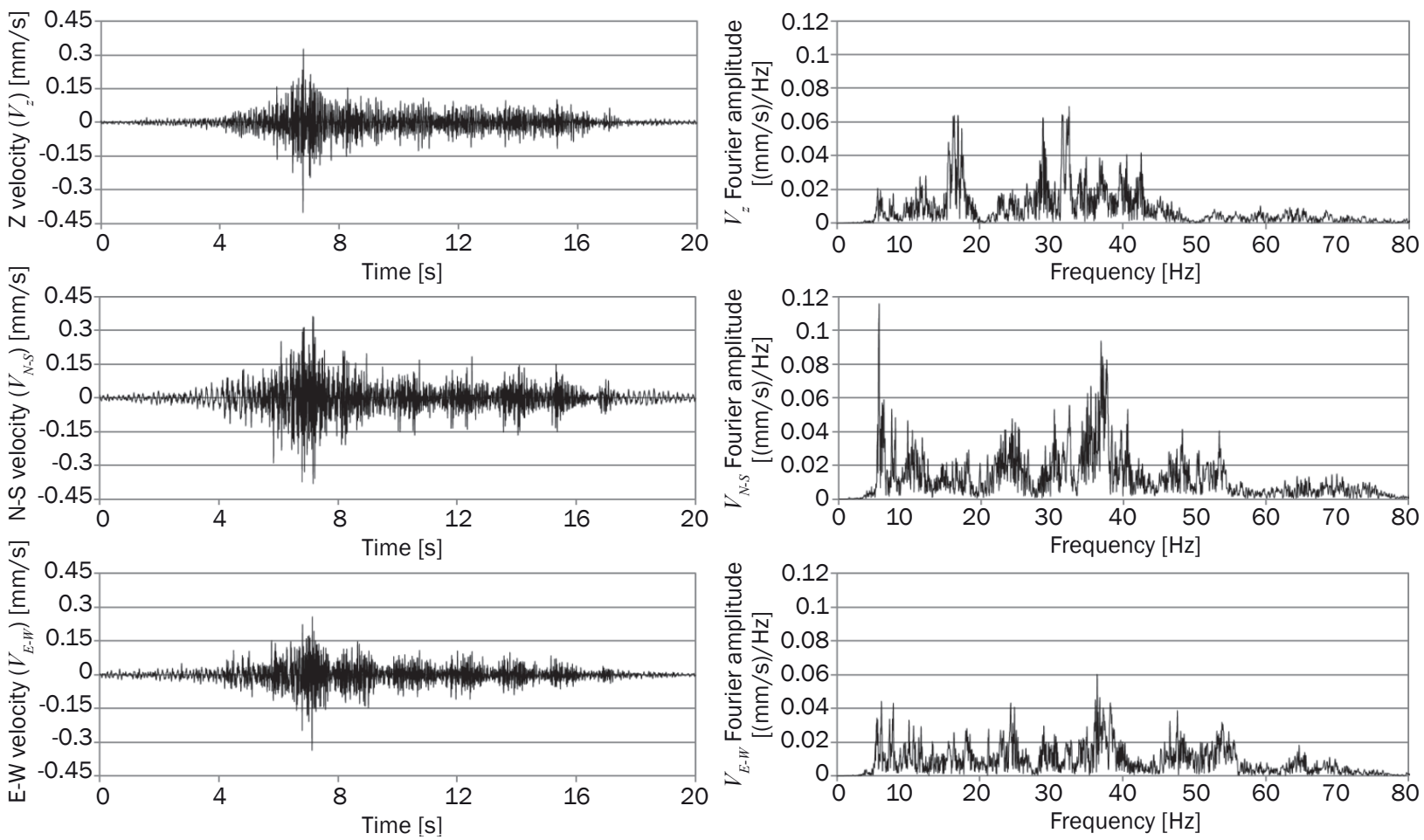

Figure 3 - Vertical (Z), north-south (N-S), east-west (E-W) velocity time histories and corresponding Fourier spectra of Train 4 in Test $10 \mathrm{~A}$
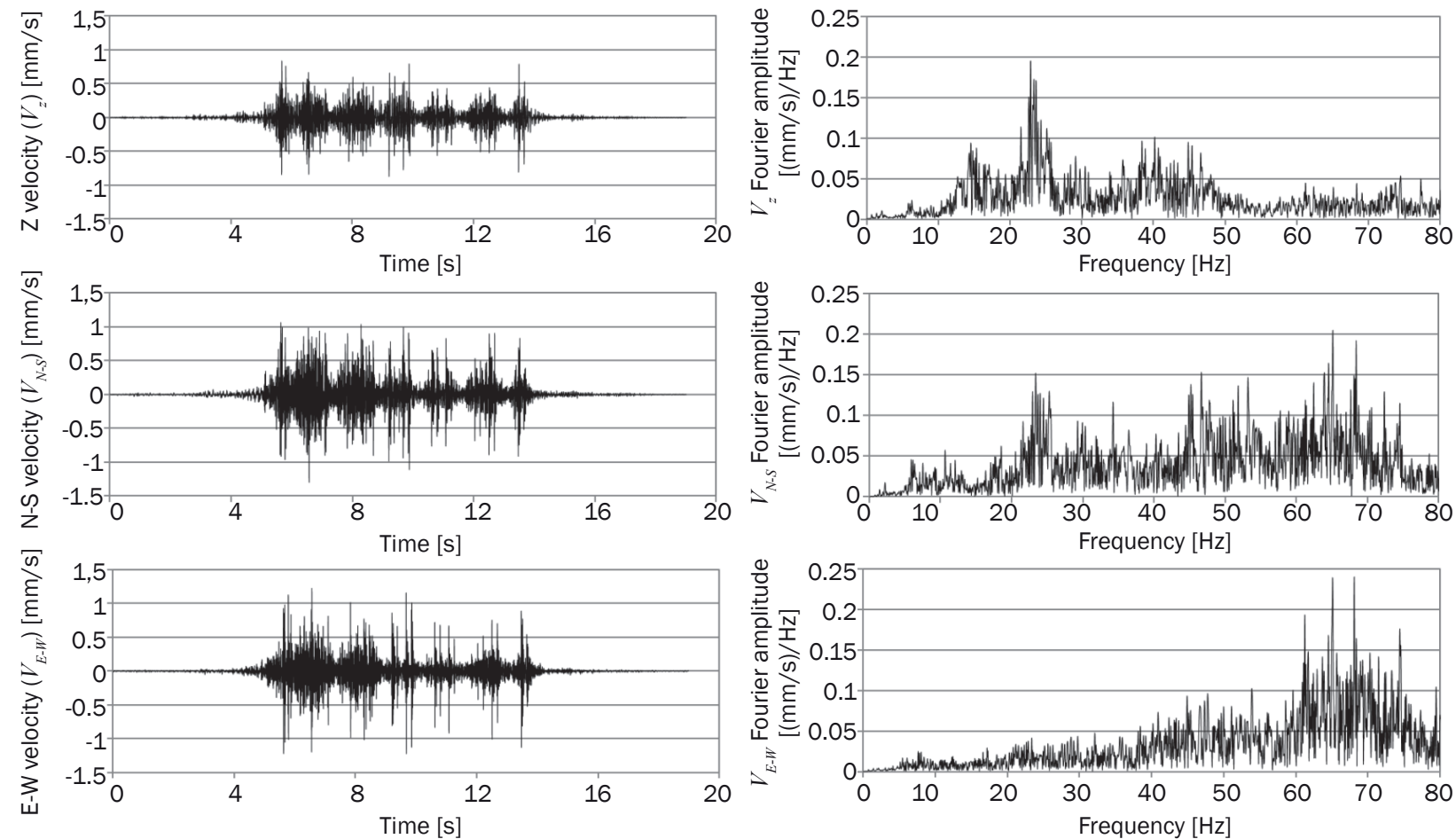

Figure 4 - Vertical (Z), north-south (N-S), east-west (E-W) velocity time histories and corresponding Fourier spectra of Train 2 in Test 11C

\section{NUMERICAL MODELLING}

Although the buildings in the surveyed areas are not the same, they have quite a lot of similar properties. Therefore, a sample of five typical model buildings were selected as representative as possible of most investigated buildings to study the building response with different dynamic properties. Thus, structural frames of 3-story, 5-story, 6-story, 8-story and 9-story reinforced concrete (RC) buildings were designed. 
Figure 5 depicts the geometrical dimensions of the buildings of which the column dimensions are given in Table 3. Beams having flanged cross-sections were assigned height of $50 \mathrm{~cm}$, width of $30 \mathrm{~cm}$, and flange width of $70 \mathrm{~cm}$ for exterior beams and $100 \mathrm{~cm}$ for the interior beams. The slabs have a thickness of $10 \mathrm{~cm}$.

Three-dimensional finite element model of each building was created in the structural analysis modelling program SAP2000 Version16 [12]. In the simulation of the RC models, uni-dimensional (1-D) frame elements were used for the columns and beams and
2-D shell elements were used for the slabs. A Young's modulus of 27,000 MPa for concrete and 200,000 MPa for steel; a Poisson ratio of 0.2 for concrete and 0.3 for steel were considered for the RC buildings. The unit weight of the RC material is taken as $25 \mathrm{kN} / \mathrm{m}^{3}$. The buildings were assumed to rest on sufficiently stable soil and thus the columns were modelled as fixed at each base.

Modal analysis and linear time-history analyses were applied to the models. In the time-history analyses, three train-induced ground motions were

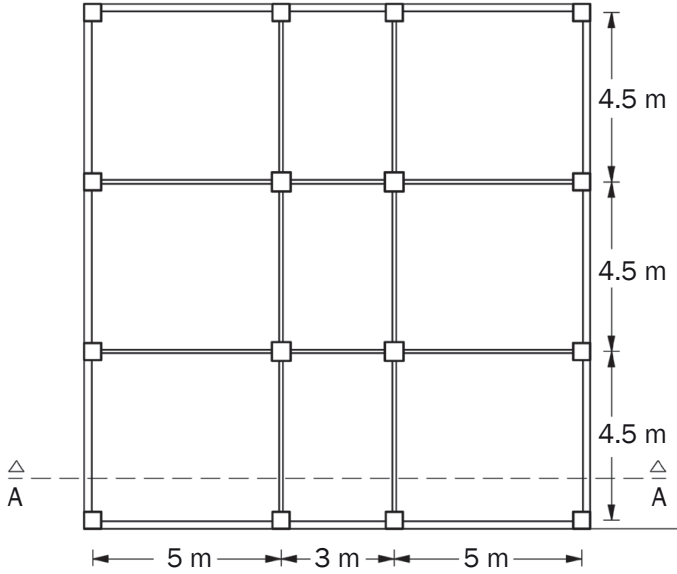

Top floor plan of a 9-story building

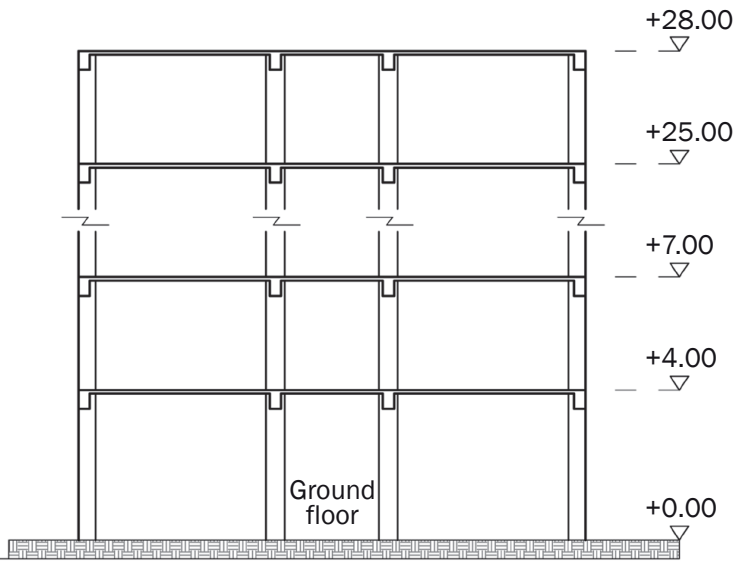

Section A-A

Figure 5 - Three-dimensional load-carrying frame

Table 3 - Column dimensions used in the structural modelling

\begin{tabular}{|c|c|c|c|c|c|}
\hline \multicolumn{6}{|c|}{ Internal Columns [mm] } \\
\hline Floor & 3-Story & 5-Story & 6-Story & 8-Story & 9-Story \\
\hline 9 & & & & & $450 \times 450$ \\
\hline 8 & & & & $450 \times 450$ & $450 \times 450$ \\
\hline 7 & & & & $450 \times 450$ & $450 \times 450$ \\
\hline 6 & & & $400 \times 400$ & $450 \times 450$ & $450 \times 450$ \\
\hline 5 & & $400 \times 400$ & $400 \times 400$ & $450 \times 450$ & $500 \times 500$ \\
\hline 4 & & $400 \times 400$ & $400 \times 400$ & $500 \times 500$ & $500 \times 500$ \\
\hline 3 & $350 \times 350$ & $450 \times 450$ & $450 \times 450$ & $500 \times 500$ & $500 \times 500$ \\
\hline 2 & $400 \times 400$ & $450 \times 450$ & $450 \times 450$ & $500 \times 500$ & $500 \times 500$ \\
\hline 1 & $400 \times 400$ & $450 \times 450$ & $450 \times 450$ & $500 \times 500$ & $500 \times 500$ \\
\hline \multicolumn{6}{|c|}{ External Columns [mm] } \\
\hline Floor & 3-Story & 5-Story & 6-Story & 8-Story & 9-Story \\
\hline 9 & & & & & $400 \times 400$ \\
\hline 8 & & & & $400 \times 400$ & $400 \times 400$ \\
\hline 7 & & & & $400 \times 400$ & $400 \times 400$ \\
\hline 6 & & & $400 \times 400$ & $400 \times 400$ & $400 \times 400$ \\
\hline 5 & & $350 \times 350$ & $400 \times 400$ & $400 \times 400$ & $450 \times 450$ \\
\hline 4 & & $350 \times 350$ & $400 \times 400$ & $450 \times 450$ & $450 \times 450$ \\
\hline 3 & $350 \times 350$ & $400 \times 400$ & $400 \times 400$ & $450 \times 450$ & $450 \times 450$ \\
\hline 2 & $400 \times 400$ & $400 \times 400$ & $400 \times 400$ & $450 \times 450$ & $450 \times 450$ \\
\hline 1 & $400 \times 400$ & $400 \times 400$ & $400 \times 400$ & $450 \times 450$ & $450 \times 450$ \\
\hline
\end{tabular}


applied simultaneously in three orthogonal directions [Z, N-S, and E-W] to determine the structures' dynamic response because vibrations of train passages are more noticeable with distinct intervals and have higher vibration amplitudes than road-traffic-induced vibrations. Furthermore, soil properties control more the frequency content of ground vibrations at a point. Thus, applied ground motions have relatively different frequency contents and vibration levels. This was considered appropriate in terms of potential interactions of ground motions with the model buildings in this parametric study. Due to the relatively low amplitudes of resulting ground motions, structures only vibrate within their linear-elastic range. Therefore, linear-elastic force-deformation relationships were adopted in the analyses. A modal damping of $5 \%$ was assumed for all vibration modes.

\section{RESULTS AND DISCUSSION}

Personal interview surveys, vibration measurements and numerical analyses results are discussed with their potential implications in the following sections.

\section{Survey results}

The age of the interviewees ranged from 20 to 70 years; the majority being concentrated from 20 to 50 years (Figure 6). The overall sensitivity was $84 \%$, which is slightly larger than the value (72.6\%) in the survey study by [13]. As such, while $37 \%$ found the vibrations slightly perceptible, $47 \%$ found them easily perceptible. Those who do not feel the vibrations at all comprise only $16 \%$ of the population (Figure 6). Vibrational perception by the majority of the respondents critically suggests that this is a communal issue which needs to be addressed more in socio-vibrational studies of changing urban environment. Accordingly, their effects can be regulated and minimized.

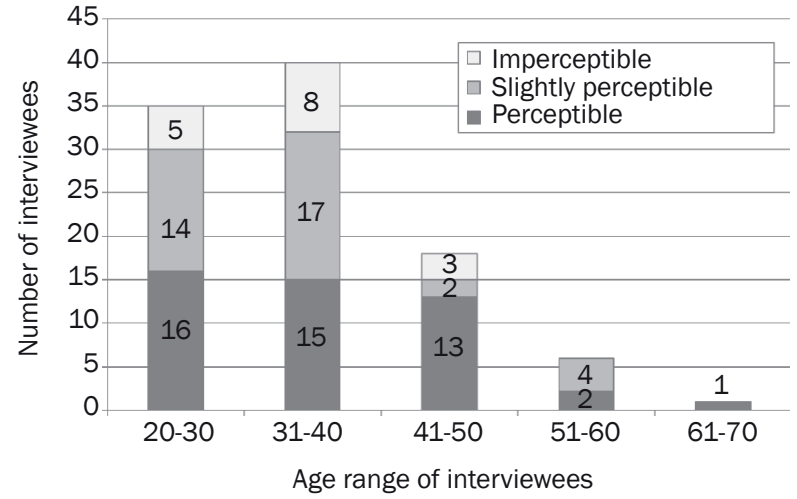

Figure 6 - Sensitivity of people to traffic-induced vibrations

Frequency of feelings of people about traffic-induced vibrations is illustrated in Figure 7 . The greatest concern about the effects of vibrations is expressed during sleeping and resting at home and during daily house activities because people get most sensitive to physical and mental disturbances when they are in need of silence. Notably, the percentage of occupants being disturbed at least "often" during resting and doing housework are $65 \%$ and $62 \%$, respectively. Not only bodily vibrations but also the vibrations of the structural system of their buildings and the vibrations of fittings are perceived by occupants with considerable frequency. Interestingly, there is no occupant who does not feel the structural vibrations. The resulting anxiety about potential structural damage is also evident in Figure 7. As such, $68 \%$ of the interviewees at least "sometimes" feel anxious about excitations. It is apparent that vibrations transmitted to the structure have sufficiently strong amplitudes and affect the occupants' comfort to such an extent that the majority complains about the frequency of vibrations. Therefore, mathematical modelling of similar structures to quantify the levels of structural vibrations and vibration transmission seemed necessary.

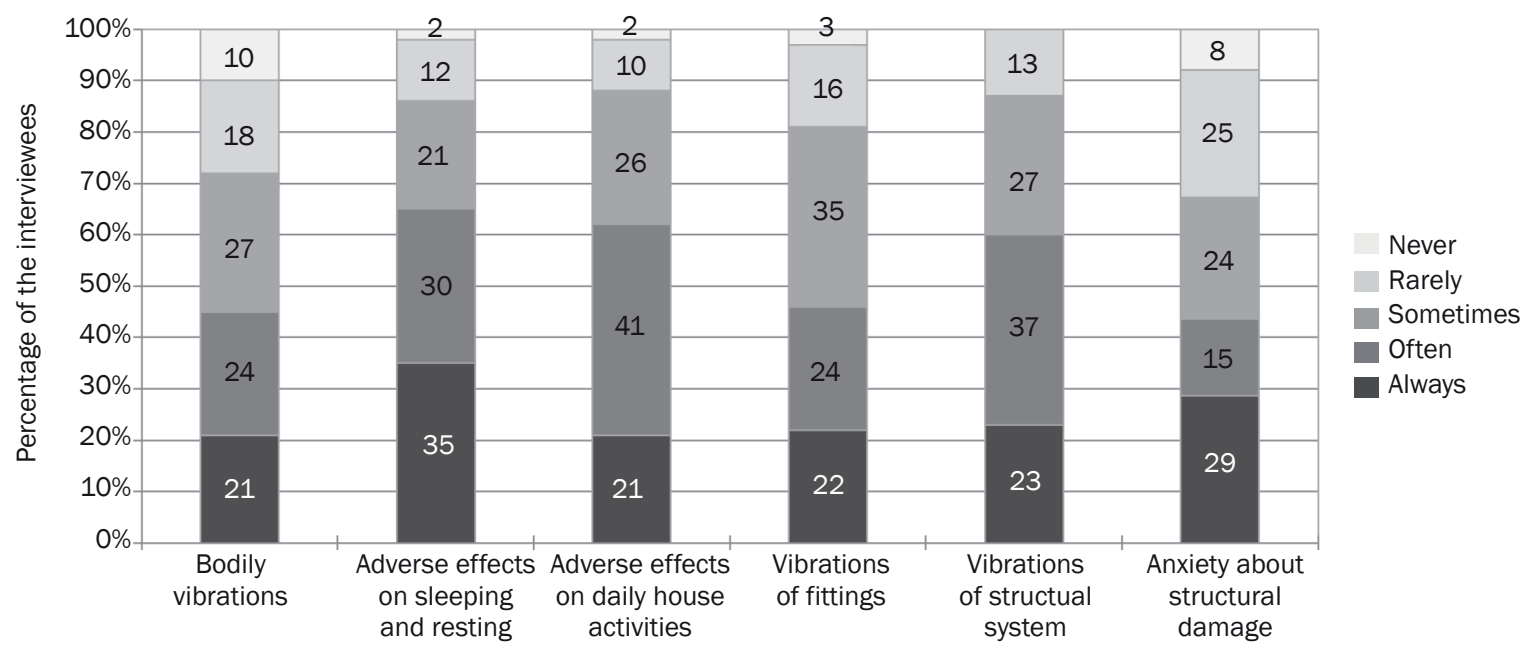

Figure 7 - Frequency of the feelings of people due to traffic-induced vibrations shown in the horizontal axis with respect to the number of interviewees 


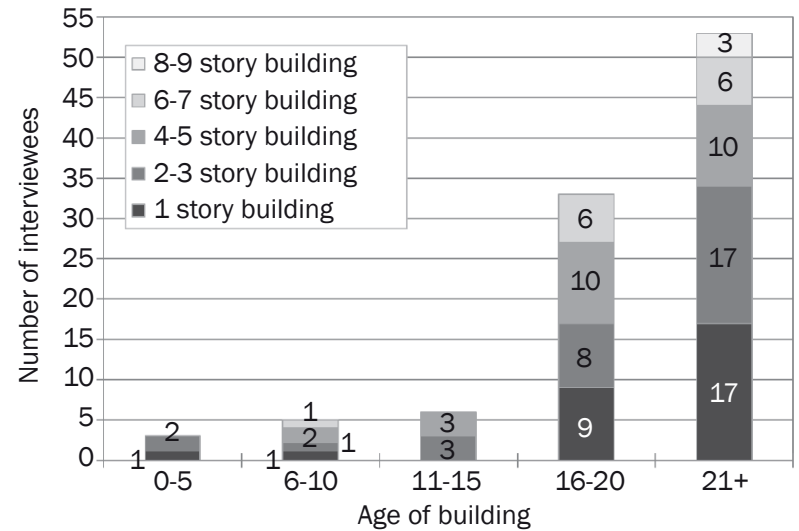

Figure 8 - Distribution of occupants with respect to age range of their buildings and number of floors

Most of the buildings (53\%) came out older than 20 years in these densely populated areas (Figure 8). Only $14 \%$ of the buildings are younger than 15 years. Actually, the mid-rise RC structures constructed before 1980 are the most prevalent in the surveyed areas and these buildings are also reported to be the most vulnerable building class to strong ground motions in "Earthquake Risk Assessment for İstanbul Metropolitan Area" [11].

The interviewees from a total of 38 buildings also answered the questions about their buildings. Closeness of the buildings to the transportation networks together with their base area and number of stories are shown in Figure 9, where each circle represents a building. The survey reflects that large concentrations of buildings are located in close proximity to the traffic routes. This is to blame for disturbing effects of vibrations reported by $65 \%$ of the interviewees. The rest of the occupants attribute these disturbing effects to the weakness of structures, high speed of vehicles and traffic density. Notably, 32 out of 38 buildings are closer than $8 \mathrm{~m}$ to the vibration sources and they are obviously the most vulnerable ones to the vibrations. Additionally, the most common "number of stories" and "base areas" of the investigated buildings helped select the representative building characteristics for numerical modelling to assess the impact of traffic-induced ground motions.

Maintenance of the buildings is another key parameter which has a major impact on the performance of buildings. It is apparent in Figure 10 that adequate maintenance of buildings declines with the building age. More than half of the buildings are very poorly maintained. The survey reveals that only $13 \%$ of the buildings are well-maintained. Lack of maintenance unfortunately increases the impact of vibrations as the deterioration processes of buildings accelerate. The resulting poor building conditions such as reduction in serviceability, load carrying capacity and safety of structures may comprise some of the undesirable consequences. As a structural trait, soft-story phenomenon is also responsible for the impact of ground vibrations. Soft story problem was observed in 92\% of the buildings due to large windows, wide doors, and large unobstructed commercial spaces on the ground floors. Such structures are possibly less able to withstand lateral forces such as earthquakes or traffic-induced ground motions since they are laterally more flexible and can amplify the ground vibrations.

Time of occurrence of the vibrations in a day is another major factor in occupant perception. According to the survey, 54\% of the interviewees generally feel the vibrations between 18:00-24:00 while 22\% and $16 \%$ of them perceive the vibrations between 12:00-18:00 and 24:00-06:00, respectively. This suggests that people mostly feel the vibrations when they need rest at night, late in the evening and early in the morning, which makes it a social problem. This is the main reason why $95 \%$ of the interviewees would like authorities to reorganize traffic regulations to reduce the effects of traffic-induced vibrations on people and structures.

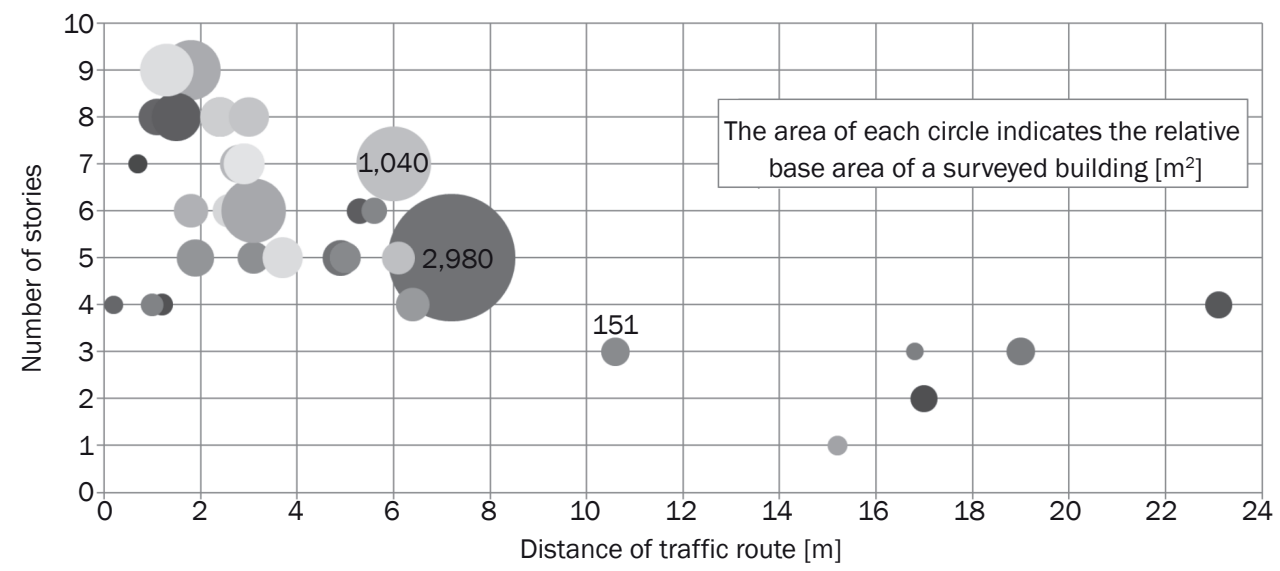

Figure 9 - Relationship between the proximity of buildings to the traffic routes, number of floors and the base area of the investigated buildings 


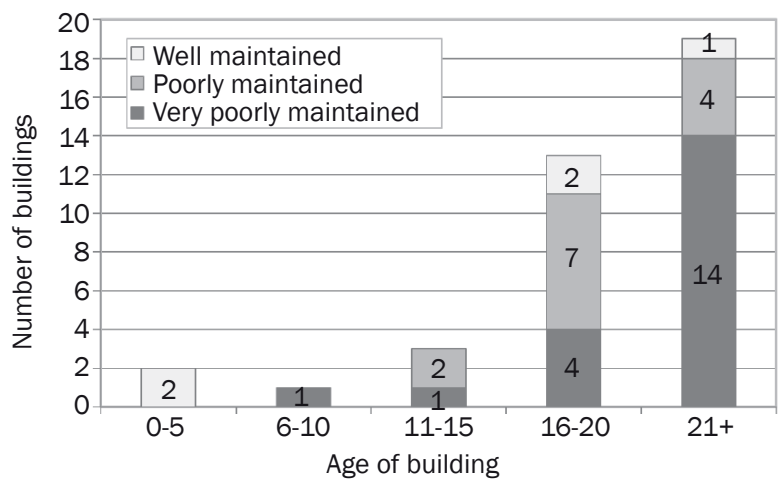

Figure 10 - Maintenance of the buildings with respect to their age

Regarding vehicle type, while interviewees who live close to road traffic only get disturbed by automobiles $(78 \%)$ and buses (22\%), those living close to both road and railway traffic get disturbed mostly by trains (57\%). Vibrations induced by train traffic pose a greater concern than those induced by road traffic, possibly because larger car weights and higher speeds of trains result in higher-amplitude and wider-frequency ground vibrations with considerably extended duration, providing a greater possibility to interact with structures. This consideration made train-induced vibrations more worthy of inclusion in the time-history analyses of the mathematical RC model buildings.

\section{Vibration measurement and numerical analyses re sults}

Vibrations were recorded on the ground by Sirkeci-Halkalı railway line to understand their characteristics and to use them in the time-history analyses. Therefore, data processing included baseline correction to avoid shifts from the baseline, and filtering of the signals with a $3^{\text {rd }}$ order, low-pass, Butterworth filter at $100 \mathrm{~Hz}$ to eliminate non-essential noise and disturbances. This is because most of the vibrational energy appeared to be below $100 \mathrm{~Hz}$ and human perception of vibrations is usually examined in frequency ranges below $100 \mathrm{~Hz}$ [13]. Acceleration time histories of train passages were obtained by differentiating recorded velocities in Tests $1 \mathrm{~A}, 10 \mathrm{~A}$ and $11 \mathrm{C}$ and applied at the base of the finite element models of each $\mathrm{RC}$ building as input motions simultaneously in three orthogonal directions [Z, N-S, and E-W]. The maximum displacement, velocity, and acceleration responses at each story level of five model buildings, obtained from time-history analyses against three different train-induced ground motions, are shown in Figures 11, 12, and 13 , respectively. In modal analyses, due to the high frequency nature of vibrations, the first 30 modes were considered to ensure around $90 \%$ of modal participation mass ratio (MPMR). Table 4 presents the modal vibration frequencies $(f)$ and MPMRs $\left(\delta_{x}, \delta_{y}, \theta_{z}\right)$ in $\mathrm{x}$ and y directions, and about $z$ axis, respectively. MPMR provides a measure of how important the mode is for computing the response to the acceleration loads in each of the three global directions. Therefore, MPMR values have considerable implications for understanding the contribution of modes of structural vibrations to overall building response to traffic-induced vibrations.

The vibration levels of each ground motion in all directions are approximately equal. This is because recorded vibrations result from the superposition of body and surface waves with different phases, coming from various locations. Thus, such waves can shake the nearby buildings in any direction. In general, the greatest ground vibration amplitudes occur in Test1A while amplitudes in Test11C are slightly higher than those in Test10A, depending on the distance of measurement points to the railway line (Figures 2-4). The effect of this is also seen predominantly in the displacement and velocity responses of the model buildings (Figures 11-13).

A remarkable likeness of the variation of vertical displacement, velocity and acceleration along the height of the buildings is noteworthy (Figures 11-13). As expected, the response in the vertical direction generally becomes greater with the height of the buildings due to causing modes of vertical structural vibrations. However, lateral responses throughout the building height demonstrate a variable pattern and thus the largest lateral responses do not necessarily occur at the top stories. This is because structures amplify ground vibrations dependent on their dynamic properties as well as ground motion characteristics.

Lateral displacements along the building height differ markedly (Figure 11). Significant difference in displacement response to different train-induced ground excitations is also evident. While lateral displacement response to Test1A motion varies profoundly from one story to the other, response to Test10A or Test11C motions varies comparatively slightly less. The reason for this is that the principal frequencies of traffic excitations are likely to coincide with the higher modal frequencies of the buildings. Such that, higher modes of buildings may tend to have larger modal displacements at lower stories, at frequency levels close to those of traffic excitations. This is critical as it is different from building response to other forms of ground vibrations, for instance seismic excitation. If the MPMRs are large enough at higher modes, the building response to traffic vibrations becomes much more notable. For instance, the displacement response of the 3-story building to the ground motion recorded in Test 1 is greater at the $1^{\text {st }}$ floor than the $2^{\text {nd }}$ floor in $\mathrm{x}$-direction (Figure 11) since the $5^{\text {th }}$ mode vibration frequency of a 3-story building $(8.20 \mathrm{~Hz})$, generating a larger displacement at the $1^{\text {st }}$ floor, is within $4.8 \%$ of the first principle frequency of the Test 1 motion $(7.80 \mathrm{~Hz})$ with a $5^{\text {th }}$ MPMR of $9.6 \%$ (Table 4). Similarly, the displacement response of a 6-story building to the ground 

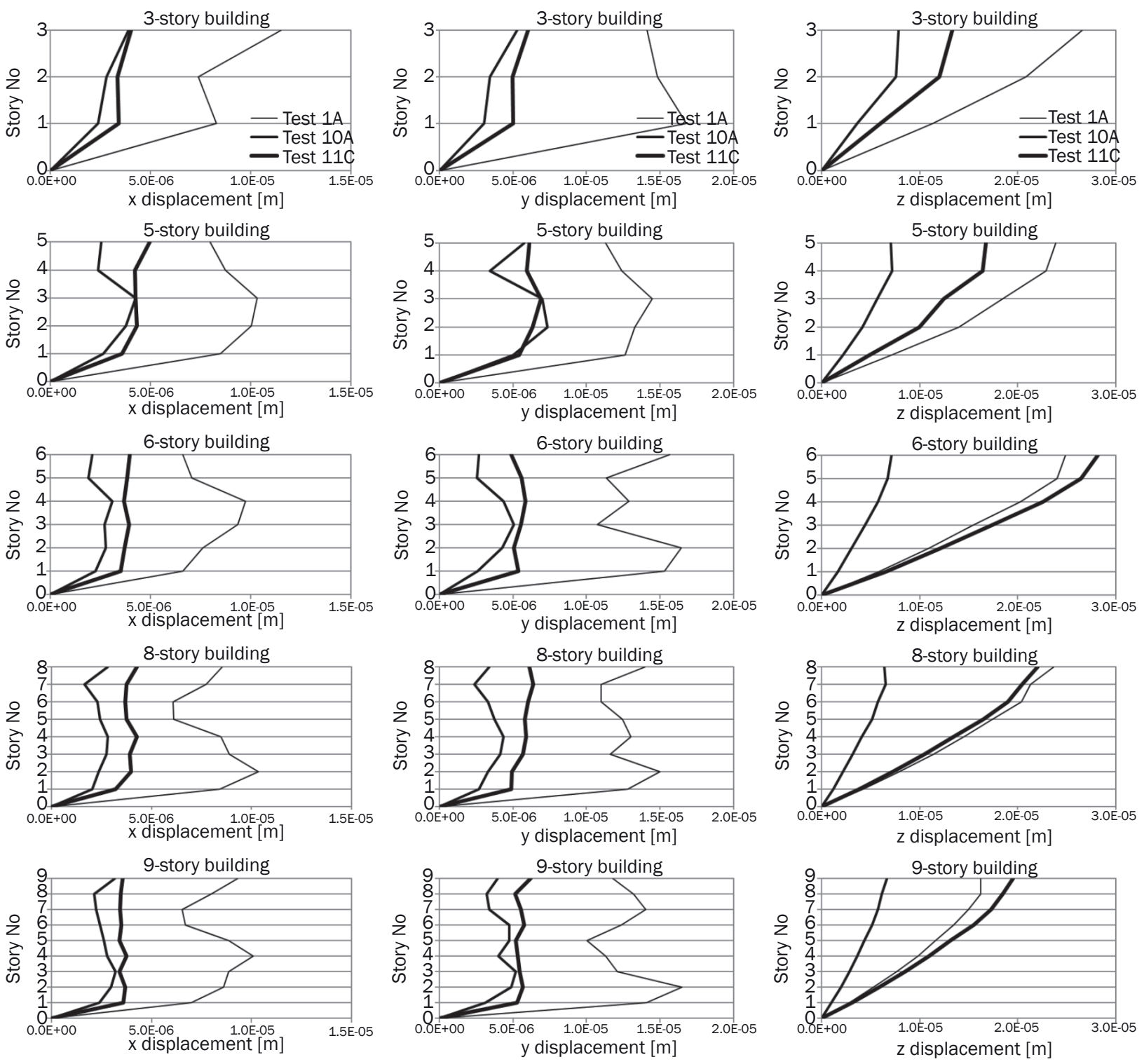

Figure 11 - Maximum displacement responses of RC model buildings at story levels

motion recorded in Test 1 is larger at the $1^{\text {st }}$ and $2^{\text {nd }}$ floors than the $3^{\text {rd }}$ floor in y-direction (Figure 11) since the $8^{\text {th }}$ mode vibration frequency of the 6 -story building $(8.32 \mathrm{~Hz})$, generating a larger displacement at the $1^{\text {st }}$ and $2^{\text {nd }}$ floor, is within $6 \%$ of the first principle frequency of the Test 1 motion $(7.80 \mathrm{~Hz})$ with an $8^{\text {th }}$ MPMR of $3.1 \%$ (Table 4). Even though the MPMR of $3.1 \%$ is not a large value, its effect is noticeable in response because lower modal frequencies of the structure coincide with extremely small-amplitude frequencies of the train-induced ground vibrations.

Lateral velocity response through the height of the buildings varies depending on the ground motions (Figure 12). Although response to Test1A and Test11C motions differs notably, response to Test10A motion remains virtually unchanged. This behaviour arguably implies that higher modes of vibration contribute to a relatively lesser degree in response to Test10A motion.
Slightly different behaviour is observed in acceleration response. As such, the largest lateral acceleration response interestingly appears at the first or second floors of the buildings. While lateral acceleration response is almost constant throughout the height of 3-, 5- and 6-story buildings, nearly a zigzag pattern is observed for 8- and 9-story buildings (Figure 13). This type of behaviour shows possibly a larger contribution of higher modes in high-rise buildings. To exemplify, the lateral acceleration response of a 9-story building to all of the ground motions is larger at the $2^{\text {nd }}$ floor than at the $3^{\text {rd }}$ floor in $x$ - and $y$-directions (Figure 13) since the $7^{\text {th }}$ and $8^{\text {th }}$ mode vibration frequencies of a 9-story building $(6.09 \mathrm{~Hz}$ and $6.13 \mathrm{~Hz})$, generating a larger acceleration response at the $2^{\text {nd }}$ floors are within $19 \%$ and $11 \%$, respectively, of the first principle frequency of the Test 1 motion $(7.80 \mathrm{~Hz})$ in the respective directions with $7^{\text {th }}$ and $8^{\text {th }}$ MPMRs of $3.6 \%$ (Table 4) even 

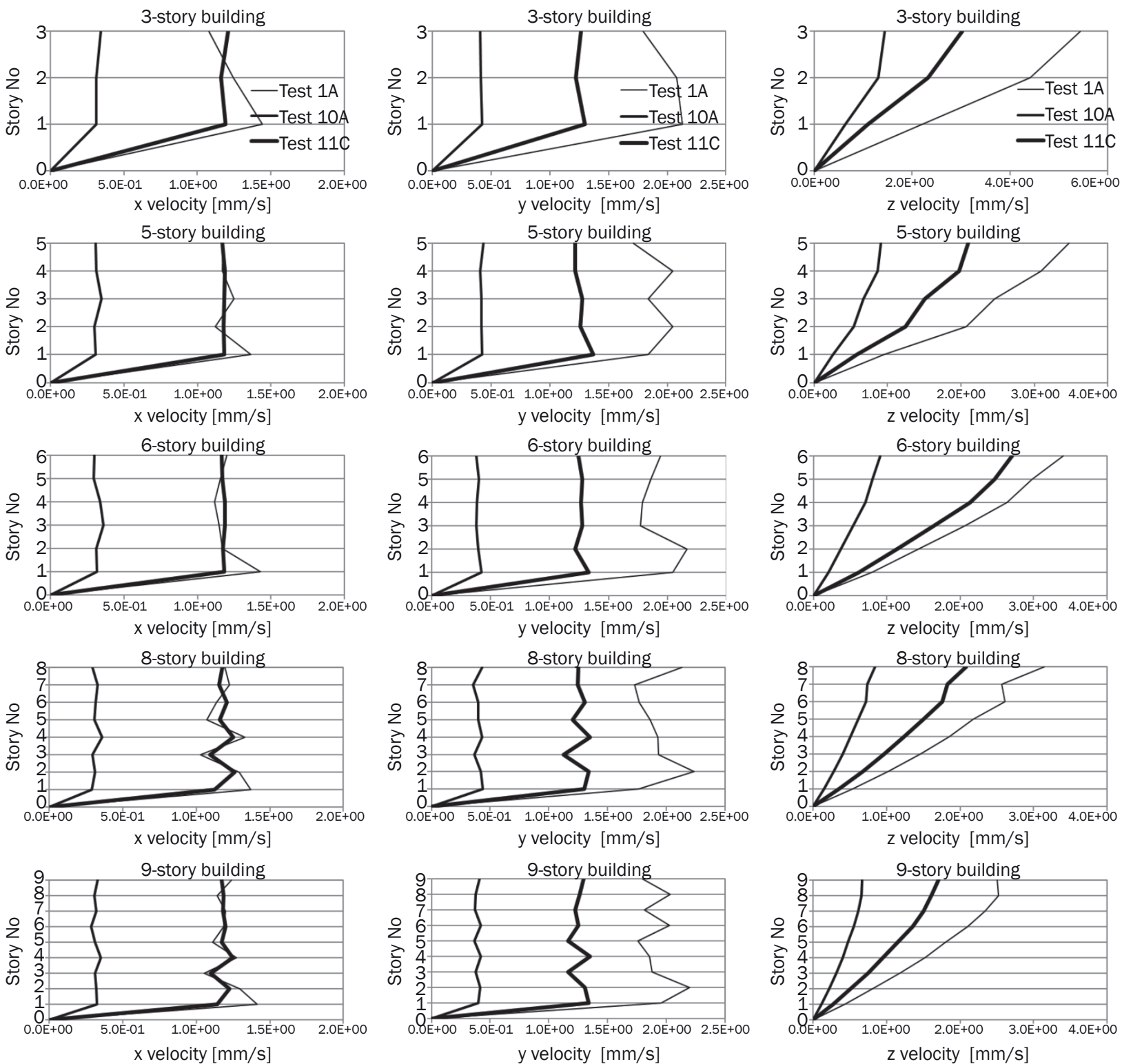

Figure 12 - Maximum velocity responses of RC model buildings at story levels

though the amplitudes of the ground vibrations are not very large. These observations demonstrate that both low and high vibration modes of buildings are involved in the dynamic responses even though most of the dominant ground motion frequencies are mainly distributed in the higher frequency ranges. In general, while lower natural frequencies of the structures with higher MPMRs coincide with lower-amplitude frequencies of the train-induced ground vibrations, higher modal frequencies of the structures with lower MPMRs coincide with the higher-amplitude principal frequencies of traffic excitations.

Figure 14 represents the maximum responses of model buildings with respect to the recorded ground motions in three directions. All lateral peak displacements appear nearly the same except for vertical displacements. For example, the 6-story building experiences much larger vertical displacement due to the ground motion (Test11C). This may be attributed to the fact that $13^{\text {th }}$ modal frequency of 6-story building $\left(f_{13}=14.18 \mathrm{~Hz}\right)$ with $74 \%$ of MPMR coincides with the first principle frequency of the vertical vibration of Test11C motion $(14.56 \mathrm{~Hz})$. Similarly, peak lateral velocities and accelerations hardly vary unlike those in vertical direction. Vertical velocity and acceleration responses are slightly larger than the lateral ones as they were determined at the centre of each central slab, which is vertically less stiff. Acceleration responses of the buildings are quite high, predominantly due to the close proximity of vibration measurement locations by the railway (Figure 1).

Crucially, peak particle velocities (PPVs) are offered by various codes and studies to evaluate the negative effects of vibrations on buildings and occupants since 


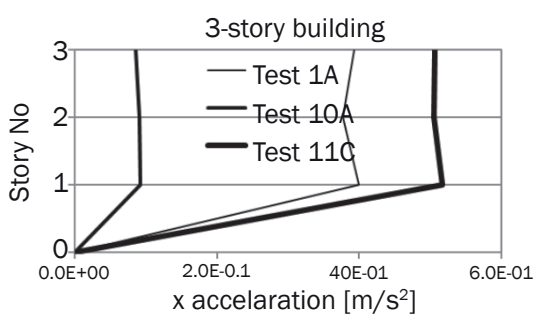

5-story building

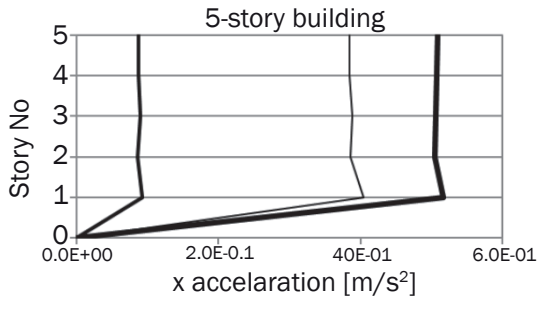

6-story building

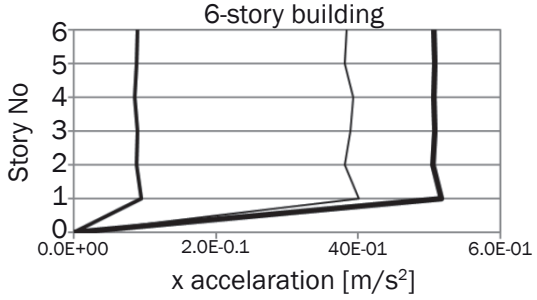

8-story building

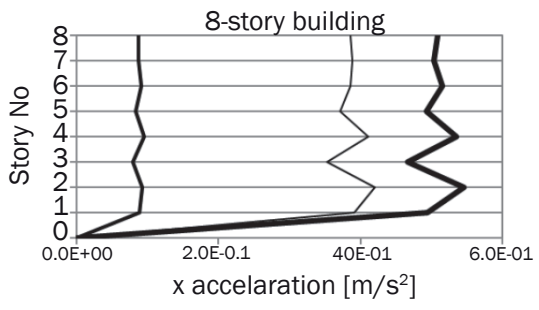

9-story building

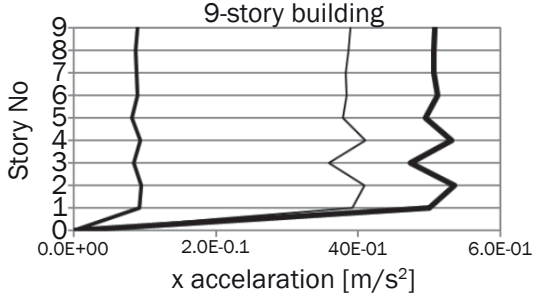

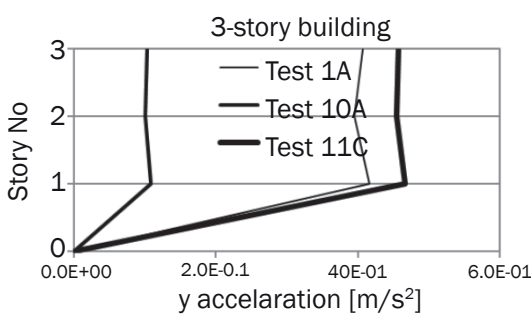

5-story building

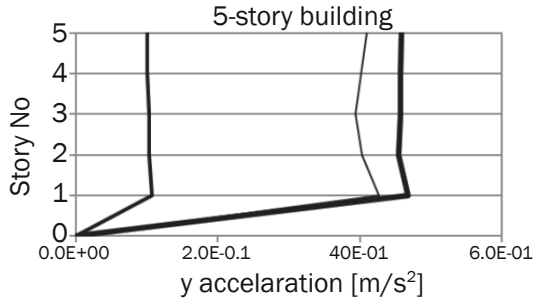

6-story building
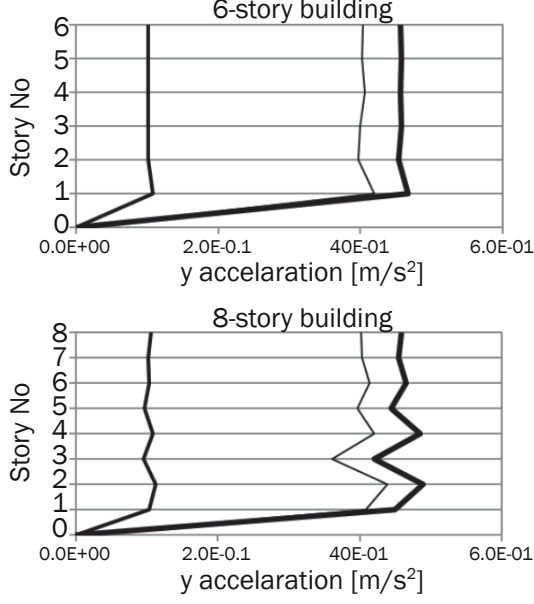

9-story building

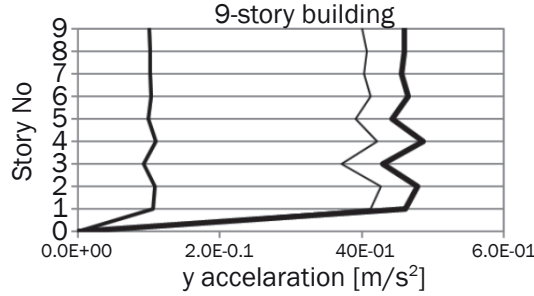

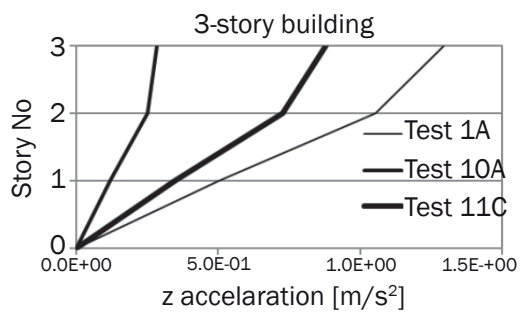

5-story building

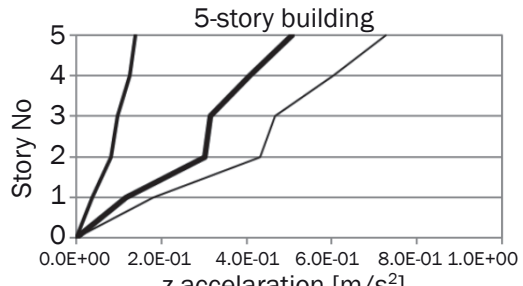

$\mathrm{z}$ accelaration $\left[\mathrm{m} / \mathrm{s}^{2}\right]$

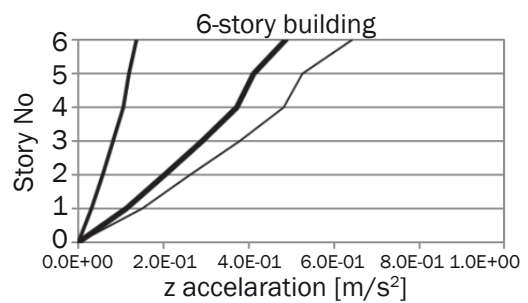

8-story bu

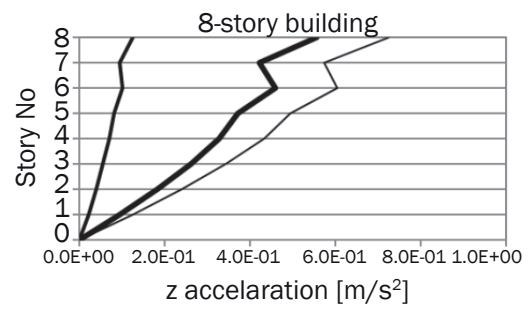

9-story building

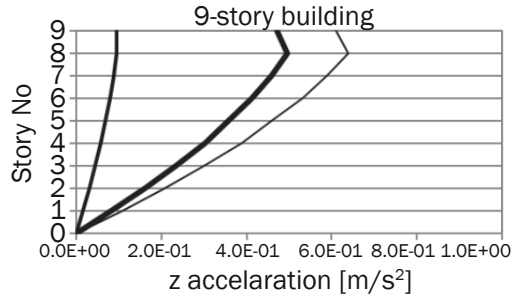

Figure 13 - Maximum acceleration responses of RC model buildings at story levels

PPV is the least frequency-dependent parameter in comparison to peak acceleration and peak displacement. Interestingly, there is a wide range of opinions on the thresholds of PPVs to evaluate the effects of vibrations. A comprehensive overview of such thresholds is given in [14]. Maximum lateral and vertical PPVs sustained by the model buildings were calculated to be $2.3 \mathrm{~mm} / \mathrm{s}$ and $5.5 \mathrm{~mm} / \mathrm{s}$, respectively. Although the level of vibrations is well below the threshold for cosmetic damage of $15 \mathrm{~mm} / \mathrm{s}$, it may easily be disturbing to the occupants according to the British Standard [15]. As such, all PPVs are larger than the perception threshold of $0.14 \mathrm{~mm} / \mathrm{s}$ [15] and $0.3 \mathrm{~mm} / \mathrm{s}$ as being perceptible to human body $[15,16]$. Vibrations above these values can unfortunately disturb, startle, cause annoyance or interfere with work activities. Critically, in all cases except the response to Test10A motion, PVV values exceeded the $1 \mathrm{~mm} / \mathrm{sec}$ threshold which causes complaints in residential environments as stated by the British Standard [15].

As seen, a far lower level of structural vibrations than those required to overstress structures is perceived by the occupants. Therefore, human response to traffic-induced structural vibrations should be globally considered as a serviceability limit state in the codes of practice. In the design of structures, time-history analyses should be carried out with site-specific traffic-induced ground motion data to check the output vibrations at each floor, for exceedance of specific limits - particularly distinctly perceptible limit $(0.8 \mathrm{~mm} / \mathrm{s})$ as reported by Wiss [16]. Undoubtedly, depending on the type of structure, 

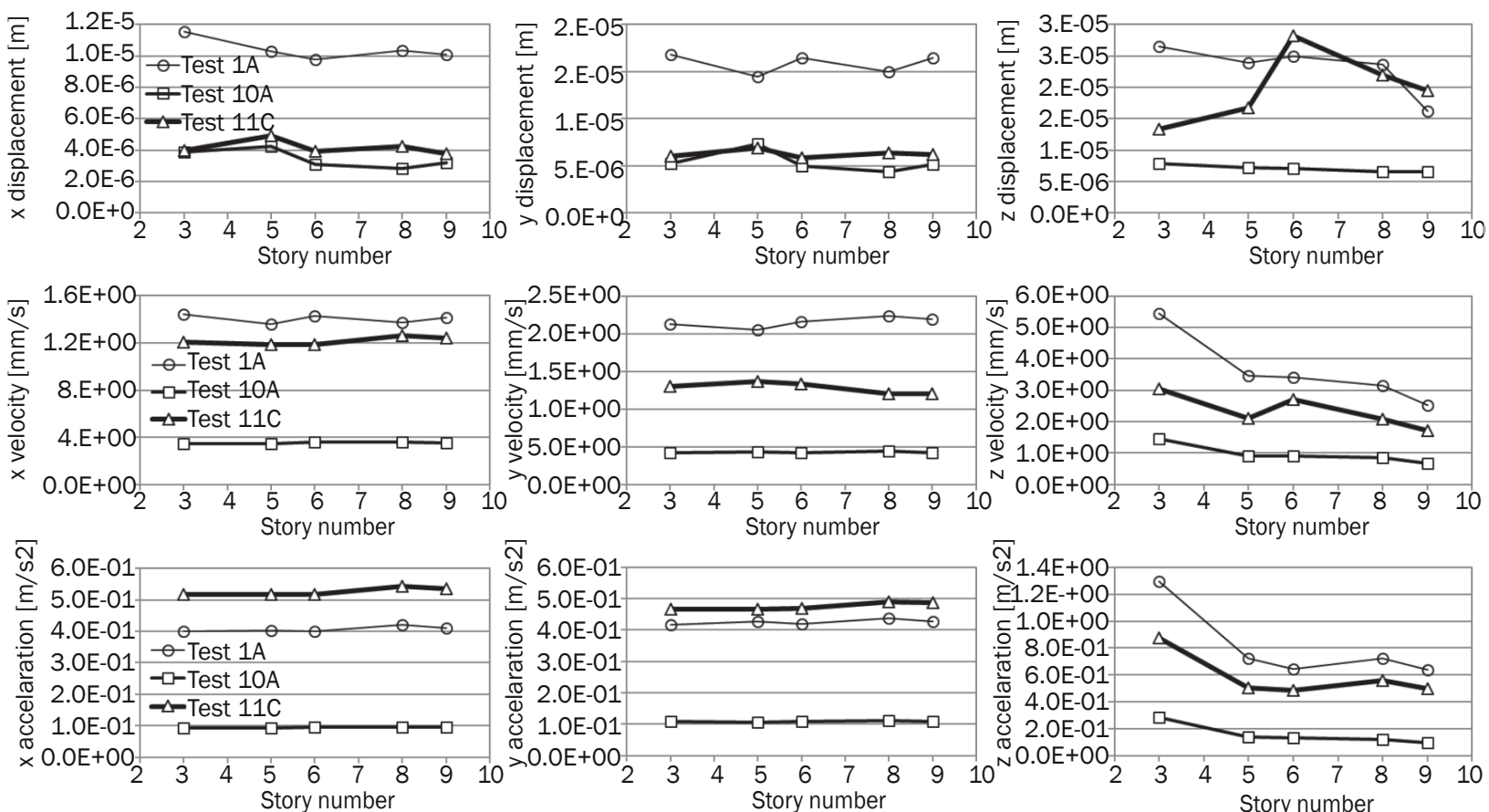

Figure 14 - Maximum responses of model buildings

Table 4 - Vibration frequencies and modal participation mass ratios of model buildings

\begin{tabular}{|c|c|c|c|c|c|c|c|c|c|c|c|}
\hline \multicolumn{2}{|c|}{ Modes } & 1 & 2 & 3 & 4 & 5 & 6 & 7 & 8 & 9 & 10 \\
\hline \multirow{4}{*}{ 3-story } & $f[\mathrm{~Hz}]$ & 2.98 & 2.98 & 3.51 & 8.19 & 8.20 & 9.61 & 13.94 & 13.97 & 16.27 & 18.24 \\
\hline & $\delta_{\mathrm{x}} \operatorname{MPMR}(\%)$ & 88.0 & 0 & 0 & 0 & 9.6 & 0 & 0 & 2.4 & 0 & 0 \\
\hline & $\delta_{y} \operatorname{MPMR}(\%)$ & 0 & 88.0 & 0 & 9.5 & 0 & 0 & 2.4 & 0 & 0 & 0 \\
\hline & $\theta_{\mathrm{z}}$ MPMR (\%) & 0 & 0 & 88 & 0 & 0 & 9.5 & 0 & 0 & 2.4 & 0 \\
\hline \multirow{4}{*}{ 5-story } & $f[\mathrm{~Hz}]$ & 1.93 & 1.94 & 2.19 & 5.46 & 5.47 & 6.11 & 9.50 & 9.52 & 10.57 & 12.57 \\
\hline & $\delta_{\mathrm{x}} \operatorname{MPMR}(\%)$ & 84.3 & 0 & 0 & 10.7 & 0 & 0 & 3.1 & 0 & 0 & 1.3 \\
\hline & бy MPMR (\%) & 0 & 84.3 & 0 & 0 & 10.7 & 0 & 0 & 3.1 & 0 & 0 \\
\hline & $\theta_{\mathrm{z}}$ MPMR (\%) & 0 & 0 & 84.6 & 0 & 0 & 10.5 & 0 & 0 & 3.1 & 0 \\
\hline \multirow{4}{*}{ 6-story } & $f[\mathrm{~Hz}]$ & 1.62 & 1.63 & 1.86 & 4.83 & 4.84 & 5.60 & 8.31 & 8.32 & 9.48 & 11.65 \\
\hline & $\delta_{\mathrm{x}}$ MPMR (\%) & 84.4 & 0 & 0 & 10.3 & 0 & 0 & 3.1 & 0 & 0 & 0 \\
\hline & $\delta_{y} \operatorname{MPMR}(\%)$ & 0 & 84.4 & 0 & 0 & 10.4 & 0 & 0 & 3.1 & 0 & 1.4 \\
\hline & $\theta_{\mathrm{z}}$ MPMR (\%) & 0 & 0 & 85.6 & 0 & 0 & 9.4 & 0 & 0 & 3.1 & 0 \\
\hline \multirow{4}{*}{ 8-story } & $f[\mathrm{~Hz}]$ & 1.34 & 1.35 & 1.55 & 3.90 & 3.92 & 4.44 & 6.80 & 6.84 & 7.65 & 9.67 \\
\hline & $\delta_{\mathrm{x}} \operatorname{MPMR}(\%)$ & 81.2 & 0 & 0 & 11.4 & 0 & 0 & 3.4 & 0 & 0 & 2.0 \\
\hline & $\delta_{y}$ MPMR (\%) & 0 & 81.1 & 0 & 0 & 11.6 & 0 & 0 & 3.4 & 0 & 0 \\
\hline & $\theta_{z} \operatorname{MPMR}(\%)$ & 0 & 0 & 81.7 & 0 & 0 & 10.9 & 0 & 0 & 3.4 & 0 \\
\hline \multirow{4}{*}{ 9-story } & $f[\mathrm{~Hz}]$ & 1.19 & 1.20 & 1.39 & 3.46 & 3.48 & 3.96 & 6.09 & 6.13 & 6.87 & 8.56 \\
\hline & $\delta_{\mathrm{x}} \mathrm{MPMR}(\%)$ & 81.0 & 0 & 0 & 11.1 & 0 & 0 & 3.6 & 0 & 0 & 1.9 \\
\hline & $\delta_{y} \operatorname{MPMR}(\%)$ & 0 & 80.9 & 0 & 0 & 11.3 & 0 & 0 & 3.6 & 0 & 0 \\
\hline & $\theta_{z}$ MPMR (\%) & 0 & 0 & 81.8 & 0 & 0 & 10.4 & 0 & 0 & 3.5 & 0 \\
\hline
\end{tabular}


vibration levels to avoid architectural and structural damage should be examined as well. Structural retrofit or intervention measures such as isolation barriers inserted in the ground around buildings could be some of the potential solutions to the problem if necessary.

\section{CONCLUSION}

To assure the welfare of occupants and even safety of buildings in cities with dense traffic, the impact of intrusive traffic-induced vibrations has been analysed by both a social survey involving 100 occupants and numerical modelling of 5 typical residential buildings in 6 densely populated areas of İstanbul. The following conclusions can be drawn from the study.

1) Clear perception of the vibrations by $84 \%$ of the occupants implies that this is a social problem in large cities.

2) Reorganization of traffic regulations by authorities is needed by $95 \%$ of the occupants to reduce the effects of traffic-induced vibrations on people and structures given that buildings are mostly poorly maintained and thus vulnerable, which may accelerate the vibration-related deterioration processes.

3) Application of measured train-induced ground vibrations on model buildings in time history analyses show that both lower and higher vibration modes of buildings are involved in the overall dynamic building response.

4) While vertical responses to train-induced vibrations generally become larger with the height of the buildings, lateral responses demonstrate divergent patterns due to the effect of higher modes.

5) Modal Participating Mass Ratios of a model building help understand the contribution of higher modes depending on the modal frequencies and amplitudes of structures as well as the principal frequencies and amplitudes of traffic excitations.

6) All peak particle velocities, determined on structures, are perceptible to the human body and they predominantly exceed the thresholds which cause complaint in residential environments. Therefore, human response to traffic-induced vibrations should be globally considered as a serviceability limit state in the codes of practice because a far lower level of structural vibrations than those required to overstress structures are perceived by occupants.

7) In codes for structural design, time history analyses with site-specific traffic-induced ground motion data should be necessary to check the output vibrations, for exceedance of specific limits - particularly distinctly perceptible limit $(0.8 \mathrm{~mm} / \mathrm{sec})$.

8) Traffic-induced vibrations need to be addressed more in future research studies with other environmental stressors involving larger sample populations in today's changing urban environment.

\section{ACKNOWLEDGEMENTS}

I would like to thank Mr. Baturhan Çelebi for his logistics support, and Prof. Dr. Debra Laefer, Prof. Dr. Eser Çaktı and Mr. Ahmet Korkmaz for their assistance during the vibration measurement program.

AYKUT ERKAL, Ph.D.

E-mail: aykut.erkal@altinbas.edu.tr

İstanbul Altinbaş Üniversitesi

İnşaat Mühendisliği Bölümü

Mahmutbey Dilmenler Caddesi, No:26, 34217 Bağcılar

İstanbul, Turkey

\section{TRAFIK TITREŞIMLERININ METROPOLITEN KENTLE- RDEKI KONUT YAPILARI VE SAKINLERI ÜZERINDEKI ETKILERI}

\section{ÖZET}

$\mathrm{Bu}$ çalışma, trafik titreşimlerinin, konut yapıları ve sakinleri üzerindeki olumsuz etkilerini ölçmekte ve değerlendirmektedir. Araştırma için, dünyanın yüksek nüfuslu ve yoğun trafikli kentlerinden biri olan istanbul, örnek kent olarak seçilmiştir. Öncelikle, titreşimlerin algılanabilirliğini ve konutların fiziki durumlarını belirlemek amacıla, kentin 6 farklı bölgesinde, 100 konut sakini ile anket yapılmıştır. Sonrasında, tren sebepli yer titreşimleri, işlek bir demir yolu yakınında kaydedilmiştir. Anket verileri ve titleşim kayıtları kullanılarak, zaman tanım alanında hesap yöntemi ile 5 farklı örnek konuk yapısı analiz edilmiştir. Sonuçlar, yapıların yüksek modlarının, yapı davranışına önemli katkısının olduğunu göstermiştir. Yapı üzerinde hesaplanan maksimum partikül hızları, çoğunlukla rahatsızlık verici düzeydedir. Kritik olarak, yapı sakinlerinin \%95'i, bu global problemin etkilerini azaltmak için, yetkili kurumların, ilgili yönetmelikleri yeniden düzenlemesini istemektedir. Bu sebeple, trafik titreşimlerine karşı insan tepkisi, kullanılabilirlik koşullarının belirlenmesinde esas olmalıdır ve sahaya özgü analiz, yönetmeliklere dahil edilmelidir.

\section{ANAHTAR KELIMELER}

Trafik titreşimleri; Insan-trafik etkileşimi; Titreşim algıSI; Bina-trafik etkileşimi; Titreşim ölçümü;

\section{REFERENCES}

[1] Papagiannakis A, Raveendran B. International Standards Organization-Compatible Index for Pavement Roughness. Transportation Research Record: Journal of the Transportation Research Board. 1998;1643: 110-115. Available from: doi:10.3141/1643-14

[2] Connolly DP, Kouroussis G, Laghrouche $\mathrm{O}, \mathrm{Ho} C L$, Forde MC. Benchmarking railway vibrations - Track, vehicle, ground and building effects. Construction and Building Materials. 2015;92: 64-81. Available from: doi:10.1016/j.conbuildmat.2014.07.042

[3] Erkal A, Laefer D, Fanning P, Durukal E, Hancilar U, Kaya $Y$. Factors affecting traffic-generated vibrations on buildings and a case study: Minaret of Little Hagia Sophia Mosque. In: Nuallain NAN, Walsh D, West $\mathrm{R}$ (eds.) Proceedings of Bridge \& Infrastructure 
Research in Ireland 2010 and Concrete Research in Ireland, A joint Symposium co-hosted by UCC and CIT, 2 - 3 September 2010, Cork, Ireland.

[4] Crispino M, D’Apuzzo M. Measurement and prediction of traffic-induced vibrations in a heritage building. Journal of Sound and Vibration. 2001;246(2): 319335. Available from: doi:10.1006/jsvi.2001.3648

[5] Ivanović Ž, Bauk S. Multiphase Approach to Developing Model of Logistics for Coastal Tourist Destinations. Promet - Traffic\&Transportation. 2014;26(5): 405418. Available from: doi:10.7307/ptt.v26i5.1458

[6] Erkal A. Transmission of Traffic-induced Vibrations on and around the Minaret of Little Hagia Sophia. International Journal of Architectural Heritage. 2017;11(3): 349-362. Available from: doi:10.1080/15583058.20 16.1230657

[7] Clemente P, Rinaldis D. Protection of a monumental building against traffic-induced vibrations. Soil Dynamics and Earthquake Engineering. 1998;17(5): 289296. Available from: doi:10.1016/S0267-7261(98) 00012-8

[8] Hao H, Ang TC, Shen J. Building vibration to traffic-induced ground motion. Building and Environment. 2001;36(3): 321-336. Available from: doi:10.1016/ S0360-1323(00)00010-X

[9] Erkal A, Laefer D, Fanning P. Analyses and evaluation of building response to traffic-induced vibrations and related human disturbance. In: The Transportation Research Board (TRB) 89th Annual Meeting, 10-14 January 2010, Washington, D.C., U.S.A.

[10] TÜiK, Turkish Statistical Institute. Results of Population
Registration System, 2016. Number: 24638. General Directorate of Civil Registration and Nationality. Available from: http://www.tuik.gov.tr/PreHaberBultenleri. do? id=24638. [Accessed 31 ${ }^{\text {st }}$ January 2017].

[11] Department of Earthquake Engineering. Earthquake Risk Assessment for Istanbul Metropolitan Area. Bogazici University Kandilli Observatory and Earthquake Research Institute, Istanbul, Turkey. Executive Summary, 2002.

[12] SAP2000. (Version 16.1.1) [Software] Structural Analysis Program - Static and Dynamic Finite Element Analysis of Structures. Computers and Structures, Inc. Berkeley, California, USA. 2014.

[13] Sica G, Peris E, Woodcock JS, Moorhouse AT, Waddington DC. Design of measurement methodology for the evaluation of human exposure to vibration in residential environments. Science of the Total Environment. 2014;482-483: 461-471. Available from: doi:10.1016/j.scitotenv.2013.07.006

[14] Srbulov M. Ground Vibration Engineering, Simplified Analyses with Case Studies and Examples. London: Springer; 2010.

[15] British Standards Institution. BS 5228-2:2009+ A1:2014. Code of practice for noise and vibration control on construction and open sites - Part 2: Vibration. London: BSI; 2014.

[16] Wiss JF. Construction Vibrations: State-of-the-Art. Journal of the Geotechnical Engineering Division, Proceedings of American Society of Civil Engineers. 1981;107(2): 167-181. 